\title{
Caroline Phillips: balancing life as a journalist and a suffragette in a Scottish city.
}

\author{
PEDERSEN, $\mathrm{S}$.
}

2020

This is an Accepted Manuscript of an article published by Taylor \& Francis in Women's History Review on 3103-2020, available online: http://www.tandfonline.com/10.1080/09612025.2020.1745401. 
Balancing life as a journalist and a suffragette in a Scottish city

Sarah Pedersen, Robert Gordon University

\begin{abstract}
Aberdeen Art Gallery holds a unique collection in the history of the women's suffrage movement in Scotland: the correspondence of Caroline Phillips, woman journalist and honorary secretary of the Aberdeen branch of the WSPU, 1907-09. A Heritage Lottery Fund grant has enabled the production of an edition of this collection and other public-engagement activities, enabling an in-depth analysis of one Scottish woman's engagement with the suffrage movement. Through her correspondence, Phillips wrestled with the demands of WSPU London headquarters for more militant action, was tempted to join the Women's Freedom League, and finally saw herself and her friend Helen Fraser replaced by the Pankhursts because of a reluctance to become more militant. Because of her involvement in the suffrage movement, Phillips found it difficult to gain entrance to some political events in the city, making it impossible to complete her work as a reporter, and was threatened with dismissal by her employer. She was also torn between the demands for militant action of the WSPU leadership and her own instinct for a more conciliatory approach, in particular in relation to the dominant Women's Liberal Association in Aberdeen. Her correspondence reveals the emotional and personal costs of working for 'the cause' in a city far away from the heart of the suffrage movement, but also the fulfilling friendships that sustained and supported her.
\end{abstract}

Key words: Aberdeen; suffragette; WSPU; Pankhurst; WFL

This work was supported by the Heritage Lottery Fund under Grant SH-16-07520

Aberdeen Art Gallery holds a unique collection in the history of the women's suffrage movement in Scotland: the correspondence of Caroline Phillips, journalist and honorary secretary of the Aberdeen branch of the Women's Social and Political Union (WSPU) 190709. A Heritage Lottery Fund grant has enabled the production of an edition of this archive ${ }^{1}$ and other public-engagement activities, enabling in-depth analysis of one Scottish woman's 
engagement with the suffrage movement and insight into the organisation of a WSPU branch in the north-east of Scotland. The archive demonstrates that, despite its position in the northern-most reaches of the UK, the branch received frequent attention from the leaders of the WSPU, from both the London and Scotland leaderships. It also demonstrates the demands made of an honorary secretary of such a branch, including dealing with internal and external politics and organising the visits of luminaries such as the Pankhursts, whilst at the same time holding down a full-time job since 'honorary' secretaries were not paid. For Caroline Phillips, her devotion to 'the cause' meant that her livelihood as a woman journalist was threatened, and she was asked to choose between her job and her politics. Phillips' correspondence reveals the emotional and personal costs of working for the cause in a city far removed from the heart of the suffrage movement, but also the fulfilling friendships and support that involvement in the movement offered.

The Watt Collection, as the Caroline Phillips archive is known, consists of 56 letters plus a few other documents dating mainly from the period 1907 to 1909, when Phillips ceased to be involved in the suffrage movement in Aberdeen. Phillips' correspondents in the letters include Scottish suffragists such as Agnes Ramsay, Elizabeth Bell and Helen Fraser, but also the perhaps better known names of Christabel, Sylvia and Emmeline Pankhurst and Emmeline Pethick-Lawrence. When the correspondence starts in 1907 Phillips was in her late thirties and working as a woman journalist at the Aberdeen Daily Journal.

Caroline Phillips had been born in the small Aberdeenshire town of Kintore and was the daughter of Jane Watt and James Phillips, both school teachers. The family moved to Aberdeen when Caroline was a young child on the appointment of her father as head of the boys' department at St Paul Street School in the city. James Phillips later became head of Northfield School, Rosemount in Aberdeen. ${ }^{2}$ Caroline's brother James worked as a journalist at the Aberdeen Daily Journal, and this connection may have led to Caroline's employment at the same newspaper. In 1901 an article in the newspaper refers to her as 'lady superintendent of the Registry Department of the Aberdeen Daily Journal and Evening Express, ${ }^{3}$ and it seems that she then moved on to journalistic work for the Journal. Aberdeen was served by two daily newspapers before the First World War, and it is interesting that Phillips worked for the conservative Journal rather than the more liberal Free Press. I have suggested elsewhere ${ }^{4}$ that conservative-leaning newspapers in Scotland were able to 'have their cake and eat it' in terms of suffragette news, aiming critical salvos against the 
suffragettes in editorials but allowing more positive views of their campaign to be published in correspondence columns and women's pages. For example, a column in the Motherwell Times in 1914, purporting to be written by a woman journalist, described how she had been asked to write about a local suffrage meeting by the editor of a newspaper with Conservative leanings. 'My conscience - a fairly accommodating organ as a rule - smote me, and I blurted out, "I can't do this." "Why?" asked the editor in surprise. "Because," I said, "I believe women ought to have votes." "But, lorblissus!" cried the editor, "that's just what we want you to say!""5 The Aberdeen Daily Journal frequently published pro-suffrage letters in its correspondence columns - although on occasion the editor might comment on such letters in order to reassert the newspaper's anti-suffrage editorial line. For example, in July 1912 Helen Tollie, the-then WSPU organiser in Aberdeen, wrote a letter objecting to an anti-suffrage leader in the newspaper. While the letter was published, the editor responded with a comment under the letter: 'That women can never be similar to men is obvious, and when Suffragettes, or women generally, try to compete with men on their own ground they are not only unequal, but, as a rule, they become mere imitations of third-rate men - The Editor. ${ }^{9}$

The early twentieth century saw the appearance of 'women's pages' in Scottish local newspapers - less as a response to a demand from women than to demonstrate a female readership for the important new advertisers, department stores, and other fashion and homeware retailers. The pages were frequently written by 'lady correspondents,' who were given coy pseudonyms at the top of their columns or remained unnamed, as was the convention of the day for the majority of journalists. While these pages defined women's concerns conservatively, placing them within the domestic sphere and focusing on appearance, home-making and motherhood, ${ }^{7}$ they did raise the profile of women's activities within Scottish newspapers, in direct contrast to the previous century where women were mostly invisible in the press apart from as victims of crime. ${ }^{8}$ As a woman reporter, Caroline Phillips would have been employed to report on 'women's issues' for the Journal, which might well have led to her attending 'At Homes' or public meetings arranged by the Aberdeen Women's Suffrage Society, which had been active in the city since the 1870s and was now affiliated to the constitutional NUWSS.

The correspondence in the archive gives an interesting insight into the minutiae of the organisation of a WSPU branch in the early years of the movement. North-East Scotland at this time was a Liberal stronghold - the Chancellor Herbert Henry Asquith held a seat in 
neighbouring East Fife and Winston Churchill represented Dundee, to the south of Aberdeen, from 1908. It is not surprising, therefore, that Aberdeen was of interest to the WSPU leadership after the landslide success of the Liberal party in the general election of 1906. However, it seems that at first the city was not impressed by the suffragettes. Krista Cowman notes Teresa Billington's report on their progress in Scotland in the Labour Record and Review of October 1906, which stated that she was pleased with the progress made in East Fife, but that Aberdeen had 'failed to capitulate on the first attack' though their visit had left 'a few staunch women' to 'hold the fort and keep the question to the fore in such ways as they can'. ${ }^{9}$ It can be assumed that one of these 'staunch women' was Caroline Phillips.

Certainly, by early 1907, Caroline Phillips was busily involved in the organisation of meetings, travel and accommodation for visitors such as Emmeline and Christabel Pankhurst, Annie Kenney and Emmeline Pethick-Lawrence, as well as leaders based in Scotland such as Helen Fraser and Teresa Billington-Greig. Her correspondence offers a salutary reminder of how difficult it must have been to arrange the travels of someone like Emmeline or Christabel Pankhurst at a distance, with Phillips deputed to liaise with other organisers, such as Elizabeth Pollok in Glasgow, ${ }^{10}$ or the local Liberal MP James Murray ${ }^{11}$ in order to coordinate the Pankhurst visits north of the border.

The first letters in the archive are exchanges with Emmeline Pankhurst about a visit to Aberdeen. Mrs Pankhurst wrote that she was planning to travel around Scotland in May 1907 and wished to include Aberdeen in her schedule. She noted that 'We of the National Committee are very anxious to keep in track with the provincial Branches' and flatteringly ended 'I need hardly say how much I should like to meet you again': further evidence that Caroline Phillips had been involved in the earlier visit of the WSPU to Aberdeen in $1906 .{ }^{12}$ More letters followed, and a visit in early May was arranged, with Phillips arranging accommodation for Mrs Pankhurst at the house of the Reverend Alexander Webster and his wife. Webster was a leader of the Scots Unitarian church in Aberdeen, a Christian socialist and prolific pamphleteer. He was an influential figure in the development of socialism in Aberdeen, a member of the Aberdeen Labour Committee, and Vice-President of Keir Hardie's Scottish Labour Party. On his death in 1918 Ramsay Macdonald described him as 'a doughty champion of all radical causes, and always with the pioneers' ${ }^{13}$ 
Mrs Pankhurst asked Caroline Phillips to write to the Glasgow WSPU in order to co-ordinate her tour of Scotland. Elizabeth Pollok was honorary secretary of the Glasgow WSPU branch. She was also a member of the Labour party in that city - the Glasgow branch was particularly intertwined with socialist politics and enjoyed strong support from the socialist weekly newspaper Forward, which often campaigned for the vote for women in its pages. ${ }^{14}$ Thus Emmeline Pankhurst's planned visit to Scotland in the spring of 1907 would have put her into close contact with the socialist side of Scottish politics in both cities.

Mrs Pankhurst's letters in April 1907 were written to Caroline Phillips from the Pankhurst home in Upper Brook Street, Manchester. However, in her second letter Mrs Pankhurst revealed that she was 'giving up housekeeping $\&$ am in the midst of packing $\&$ dispersing of books, papers etc, the accumulation of many years'. She added, 'You will understand that it is not a light task.' In 1907 Emmeline Pankhurst had been forced to resign her paid work as a Registrar in Manchester, having been warned by the Registrar General that her suffragette campaigning was incompatible with the post. ${ }^{15}$ At the age of 49, therefore, Emmeline Pankhurst resigned from her job, thus losing her salary, and gave up her home in Manchester. From then on she was to live at a hotel in London in between her travels around the country. As we can see from her letter, this meant that she had to get rid of many of her personal belongings and papers because she had nowhere to store them. The personal sacrifice that Emmeline Pankhurst made for the suffrage movement is evident in this short letter. However, despite the positive tones of the correspondence, later letters in the archive suggest that the visit to Aberdeen did not go ahead at that time.

Caroline Phillips' growing involvement with the women's suffrage movement did not go unnoticed in the newsroom. The archive demonstrates clearly that Phillips used the offices of the Daily Journal as headquarters for the Aberdeen WSPU branch. Telegrams were sent to her care of the Journal, she wrote drafts of her letters on Journal and Evening Express notepaper and even used Journal postcards to write receipts for WSPU subscriptions. ${ }^{16}$ The undated draft of one letter demonstrates that her growing notoriety as a suffragette led to problems for her as a journalist. Drafting a letter to the Aberdeen Liberal Association she argued: 'Things have come to a pretty pass ... when a chief reporter is declined a press ticket for one of his own staff when she happens to be a woman and a suffragist. This is what has happened in my case and I am prevented from exercising my duties as a journalist by these coercive means. ${ }^{17}$ Evidently there was concern that Phillips would disrupt political meetings. 
She claimed in the letter that she had promised the chief reporter 'absolute silence while at the press table,' but had still been told that she would be refused admittance.

In October 1907, Phillips organised the Aberdeen contingent of a National Scottish Women's Suffrage Procession held in Edinburgh, including a special train from Aberdeen. A letter from Elizabeth Bell of the Edinburgh WSPU hints at some of the complexities involved in the organisation of such an event, involving not only the Scottish branches of the suffragist NUWSS, but also the WSPU and the newly formed Women's Freedom League (WFL), whose supporters had split from the WSPU only a month before. ${ }^{18}$ To avoid arguments about precedence, organisations processed alphabetically, which meant that the Aberdeen women were positioned right at the front, directly behind the Edinburgh WSPU contingent, which led the procession. Mrs Bell's letter made reference to a special train chartered to bring the Aberdeen suffragettes to Edinburgh and asked Phillips to check whether the large posters advertising the procession that she had sent to an Aberdeen bill-poster had really been posted around the city.

A report in The Scotsman estimated that a thousand women assembled in King's Park that afternoon to process through Edinburgh. ${ }^{19}$ From the report we know that the Aberdeen WSPU contingent came after a flute band and before the representatives from Dundee and Dunfermline. It estimated that the procession was around three-quarters of a mile in length and included fifty vehicles. While some women walked in the procession, the majority were in carriages and char-a-bancs, which were festooned in banners. The distinguishing colours of the procession were white and red, with marchers wearing rosettes, sashes, badges and armbands in these colours and carrying bannerettes. The afternoon was sunny, but with a stiff breeze, which apparently caused some problems for those ladies wearing fashionably large hats. Caroline Phillips was invited on to the platform at the meeting at Synod Hall at the end of the procession, to find herself sitting with luminaries such as Christabel Pankhurst and Sarah Elizabeth Siddons Mair of the Edinburgh National Society for Women's Suffrage, but also Charlotte Despard of the rebel Women's Freedom League. ${ }^{20}$

The early section of the archive contains several of such marks of favour. For example, Phillips was invited to a reception in London in September 1907 to celebrate the second anniversary of the imprisonment of Christabel Pankhurst and Annie Kenney, ${ }^{21}$ while a letter from Christabel on the $20^{\text {th }}$ of that month assured her that 'I am very willing to attend... any meeting'. ${ }^{22}$ It is 
not difficult to see a connection between these flattering attentions and the splitting of the suffragette ranks with the establishment of the Women's Freedom League in the autumn of 1907. Christabel's letter to Phillips went on to call for 'Unity', which was 'all that is required now to take us through the little difficulty' while a postcard from Helen Fraser of Glasgow, leader of the Federation of Scottish WSPU branches, emphasised: 'We must have meetings as we don't wish to seem disturbed here'. ${ }^{23}$ It should be noted that this brief note from Fraser ended 'my love, H.F.' in contrast to the more formal 'sincerely yours' from Christabel Pankhurst.

Several of the Women's Freedom League rebels, such as Charlotte Despard, had links to Scotland and, in particular, Teresa Billington had been the first paid organiser in the country, attracting many to the WSPU cause the previous summer. While she had ceased to work as a paid organiser on her marriage to the Scottish socialist Frederick Lewis Greig, Teresa Billington-Greig (as she now styled herself) settled in the country and continued to campaign for the WSPU in a voluntary capacity. ${ }^{24}$ Cowman notes that this freed her to be more critical of the Union's workings, and she encouraged Scottish branches to lobby the London leadership for a more democratic system with elected leaders. It is clear that Caroline Phillips was tempted by the possibilities offered by the Women's Freedom League. The archive contains several WFL pamphlets, including a copy of its constitution on which someone (Caroline?) has marked a tick next to the clause stating '[T] he National Executive Committee shall not initiate any new policy between one Conference and the next' ${ }^{25}$ There is also a winter syllabus for meetings of the Edinburgh branch of the WFL ${ }^{26}$ and an undated letter from Teresa Billington-Greig herself, clearly intent on encouraging Caroline Phillips to campaign for changes in the way in which the WSPU was run. From references within the letter it can be dated to late August 1907 and discusses potential amendments to the WSPU constitution and the need for branch representatives to be placed on the executive committee of the WSPU: 'What is vital is that as many as possible of the members should be elected by the branches and responsible to them'. ${ }^{27}$ The letter thus appears to be part of the efforts of Billington-Greig and others who had become unhappy with the growing autocracy of the Pankhursts to amend the WSPU constitution and gain more independence for individual branches at a planned September conference. In response, Emmeline Pankhurst cancelled both the constitution and the conference, precipitating the exodus of members such as Teresa Billington-Greig, Charlotte Despard, Annie Cobden Sanderson and Edith How Martyn. Since Billington-Greig had been an early recruiter for the WSPU in Scotland it is not surprising that 
many of those she had recruited now followed her into the Women's Freedom League. Women such as Anna Munro, Eunice Murray and Maggie Moffat all moved to the WFL, which opened a Suffrage Centre, bookshop and tea-room in Sauchiehall Street, Glasgow. ${ }^{28}$ Nonetheless, Caroline Phillips - and Helen Fraser in Glasgow - continued in their loyalty to the Pankhursts.

With its concern that 'we don't wish to seem disturbed', Fraser's postcard concerned plans for several of the leaders of the WSPU, including Christabel Pankhurst and Emmeline Pethick Lawrence, to travel around Scotland in the autumn of 1907 to boost the WSPU. One of the speakers mentioned, Isabella Bream Pearce, was a member of both the Glasgow WSPU and the Independent Labour Party and another contributor to the socialist newspaper Forward on the topic of women's suffrage. It was from her home that Teresa Billington-Greig had been married in February 1907. Despite their friendship, however, Mrs Pearce continued as a member of the WSPU, becoming one of the joint secretaries of its Scottish Council. One of the key themes that arises out of any study of the Scottish suffrage movement is that there were often links of close friendship between members of different organisations. In a small Scottish town there would be only be a limited number of women with an interest in the suffrage issue, and the time and resources to devote to it, and so it is not surprising that they would know each other. It is also clear that many of the women involved in the Scottish WSPU came from socialist roots and knew each other through activities such as writing for Forward. This background might be one of the reasons that so many of these women moved with Teresa Billington-Greig to the more democratic Women's Freedom League.

In November 1907 a letter from Christabel Pankhurst to Caroline Phillips hinted at problems within the Aberdeen WSPU branch. 'Mrs Mayo not long ago said she would leave the Union - it is a great pity she did not keep her word. She seems to be giving you a great deal of trouble. ${ }^{29}$ Isabella Fyvie Mayo was a local activist and author who had become associated with the WSPU from the start of its establishment in Aberdeen. However, her support for the cause led to a series of disputes, both on the platform of meetings and in the local newspapers. At one point she appeared to publicly disagree with Emmeline Pankhurst herself over the precise demands of the WSPU. It is clear that she continued to be a troublesome force within the Aberdeen WSPU branch, and the letter hints that she was challenging Caroline Phillips for its leadership. Phillips, however, had the support of headquarters. Christabel ended her letter 'I hope you will retain the Secretaryship. I think you will get on all right in a very short while.' 
A turning point in Caroline Phillips' relations with the London leadership came in December 1907. The Chancellor of the Exchequer, Henry Herbert Asquith, was invited to Aberdeen to address a meeting of the local Liberal Association at the Music Hall. There were fears that the suffragettes might try to disrupt the meeting, as had happened elsewhere in the country, and therefore it was rumoured that all women were to be banned from the meeting. This upset the influential Aberdeen Women's Liberal Association (AWLA), many of the leaders of which were also members of the constitutional Aberdeen Women's Suffrage Society.

Clashes between the WSPU and the AWLA had occurred at the start of 1907 during the South Aberdeenshire by-election campaign. Such clashes were not surprising given the WSPU policy of encouraging electors to vote for any candidate other than the Liberal. At a meeting held at the YMCA hall in Aberdeen on 31 January 1907, Helen Fraser explicitly attacked the Liberal ladies, stating that, in her opinion, women without votes had no right to belong to a political party - although of course this opinion would have put her at odds with many of her own members in Glasgow. ${ }^{30}$ At the same time, Isabella Fyvie Mayo wrote a series of letters to the newspapers attacking the constitutional Aberdeen Women's Suffrage Society, describing its members as being 'singularly effete' in their work for votes for women and being 'so entangled' with the Women's Liberal Association that little was achieved. ${ }^{31} \mathrm{~A}$ few weeks later Fraser sought to reach out to the Liberal ladies and met with them to try to persuade them not to work for the Liberal candidate during the by-election campaign. However, Mrs Black and Mrs Allan, the Honorary President and Secretary of the Aberdeen Women's Liberal Association, wrote a letter after the meeting to the Aberdeen Daily Journal explaining that they certainly would not commit to working against a Liberal candidate who had stated that he was in favour of giving the Parliamentary vote to those women who already possessed a municipal one. ${ }^{32}$ In response, Helen Fraser wrote to the Aberdeen Free Press, pointing out that there were already 420 MPs in the House of Commons who were pledged to support women's suffrage, including the Prime Minister, but as yet no vote had been forthcoming. She argued that the Prime Minister had told women to have patience, but women had been waiting for the vote for fifty years and were running out of patience. ${ }^{33}$

On the surface, relations between the WSPU and the AWLA had not improved by the time of the Asquith meeting in December 1907. In November 1907, and in her role as honorary secretary of the Aberdeen WSPU, Caroline Phillips wrote a letter to the correspondence 
columns of the Journal denouncing the cowardice of the Women Liberals and their refusal to seek an audience to discuss woman suffrage with Asquith while he was in Aberdeen. She noted that WSPU 'tactics' had been criticised at a recent meeting of the AWLA, although several pro-suffrage speeches had also been given, and suggested that the Women Liberals would sooner or later find that the WSPU approach was the only one that would achieve women suffrage: 'They may find that when they attempt to put such principles into practice, they are tackling the strongest prejudices the world has ever known; and if they really want justice granted to their sex, the treatment they receive will assuredly bring them to the "tactics" frame of mind'. ${ }^{34}$ In this letter she acted in her official position as honorary secretary of the Aberdeen WSPU and stuck to WSPU policy. A note in the archive from Lady Ramsay, the branch president, applauded the letter: 'Yr letter in the Journal is capital - the very thing. 35

However, behind the scenes, Phillips was attempting to conciliate the Liberal women. Demonstrating a much more co-operative approach than her official correspondence to the newspapers would suggest, she wrote to Mrs Allan, honorary secretary of the AWLA, suggesting that the Aberdeen suffragettes would agree not to disrupt the Music Hall meeting so that women would be allowed entrance. ${ }^{36}$ In a draft letter, written on Aberdeen Daily Journal headed notepaper, Phillips argued that 'Mr Asquith has been dealt with so effectively by the WSPU in various centres of political activity that our Aberdeen WSPU are in the mind to leave him severely alone.' She also suggested that the Aberdeen branch was too busy with other campaigning to undertake militant action against Asquith, a slightly suspect claim since Asquith's visit was evidently perceived to be an important moment for Aberdeen as a whole and the Chancellor was a high-profile target for the WSPU. However, Phillips admitted that 'I am not speaking with complete authority'. A few days later the Aberdeen leadership was forced to explain their decision. Another draft letter in the archive, this time to Lady Ramsay, is a response to the criticism of a Mrs Macdonald. 'We are prepared to take extreme measures like the others but we must, as the Independent Aberdeen WSPU, be the judges as to when and where that action is politic.... In London, at a distance, these... local matters cannot be appreciated, but they are often the things that matter a great deal. This does not affect generally our enthusiastic following of Mrs Pankhurst's policy, nor our devotion to her leadership.' 37 
Krista Cowman mentions a report in Votes for Women of November 1907 that Mrs Macdonald of Aberdeen had put her entire house at the disposal of the WSPU for two years, so she was evidently a keen supporter of the movement. ${ }^{38}$ Her criticisms of Caroline Phillips' decision not to disrupt the Music Hall meeting is another hint at disagreements within the Aberdeen branch membership.

Given that the London leadership of the WSPU had just faced down demands for more independence of action for branches in the row over the constitution, it is perhaps not surprising that the response from London was not one of approval for Caroline Phillips' decision to leave Asquith alone. Instead, Mrs Pankhurst wrote to announce that she was travelling to Aberdeen herself in order to lead an attack on the Asquith meeting at the Music Hall. ${ }^{39}$ Her letter to Phillips ended: 'There are a great many things I want to discuss with you when I come', which may have sent a shiver of anticipation through Caroline Phillips.

Mrs Pankhurst was in Aberdeen for a week and a scrappy note in the archives lists the talks and drawing-room meetings she attended. ${ }^{40}$ This included the Music Hall meeting on 19th December, described only as 'L'affaire Asquith'. Women had, after all, been allowed into the meeting, which was then disrupted by a group of suffragettes and their supporters, including the Reverend Alexander Webster, when Mrs Black, the President of the AWLA, was apparently prevented from asking a question. Acting again as the official voice of the Aberdeen WSPU, Caroline Phillips wrote to the newspaper celebrating the suffragette action and describing it as stage-managed by herself and Mrs Pankhurst: 'Mrs Pankhurst and I, who were responsible for the whole affair ${ }^{41}$ There was no mention of any attempts to conciliate the women liberals, although Phillips did note 'Kind, appreciative sentiments have been freely going the round from women Liberals. For these we are most grateful; we understand each other all the better in Aberdeen for what has happened.'

Controversy about the suffragettes' militancy raged in the city's newspapers for several days, prompting Christabel Pankhurst to write to Caroline to congratulate her on the 'Aberdeen affair'. ${ }^{42}$ Even the AWLA President appeared happy with events. In a private letter to Caroline Phillips, Mrs Black celebrated her tangential involvement with the events: 'We have all scored a victory.... I shall feel after that that I have had the honour of firing the first shot for the Women's Liberal Associations. ${ }^{43}$ 
The warm relationship between Phillips and the leaders of the AWLA continued into the new year. While Mrs Black warned that the 'Liberal women can do nothing officially,' quiet meetings were held with some of 'the more ardent reformers in our committee' ${ }^{44}$ Asquith was at this time standing for election as Rector of Aberdeen University and a public meeting was organised in January 1908 to raise awareness of the women's suffrage question. Mrs Black and Mrs Allan of the WLA were on the platform, as well as the wife of the Liberal MP for Aberdeen, James Murray, and Mrs Webster, wife of the socialist Rev. Alexander Webster. The ladies had been invited to listen to Emmeline Pethick-Lawrence, but on the day Christabel Pankhurst appeared instead. A storm of protest that the Liberal ladies had shared a platform with a notorious suffragette and a socialist was unleashed in the Aberdeen newspapers. A letter from Mrs Allan after the event demonstrates her anger at the substitution of Christabel for Emmeline Pethick-Lawrence: 'I have no hesitation in saying I do not think the WSPU "played the game".... I object strongly to Miss Pankhurst taking up the whole hour in a defence of the tactics pursued. We went to hear an educative address on Suffrage not to hear the WSPU extolled all the time. It was not courteous. We ought to have had Mrs Pethick-Lawrence. She would convert where Miss Pankhurst only irritates. ${ }^{45}$ In response, Caroline Phillips pointed out 'Both Mrs Black and yourself... have heard Christabel Pankhurst speak at least once; you could not therefore pretend to be ignorant that her speeches are political above all else. ${ }^{46}$

The plans for this meeting and WSPU agitation against Asquith's campaign for the university rectorship were apparently the last straw for the management of the Aberdeen Daily Journal. On 18th January 1908 the newspaper manager wrote to Phillips warning that continued association with the WSPU would jeopardise her position at the Journal: 'You are identifying yourself far too closely with W. S. movement, considering the position you hold here. I hear lots of protests, both inside and outside the office. I trust you will give me the assurance before Friday that henceforth you will mind your own affairs, otherwise I will have to refer the matter to the Board. ${ }^{47}$

Despite these threats, Caroline Phillips remained loyal to the Pankhursts and the WSPU. However, it is clear that she was not happy about the increasing militancy of their campaign. Correspondence from the latter half of the archive demonstrates a growing distrust and a cooling of the relationship between Phillips and the London leadership. Invitations for Emmeline Pankhurst to come to Aberdeen were turned down, plans to use a horse-drawn 
caravan to travel around the region not approved. Instead, Christabel wrote a glowing portrayal of the 'fine Scottish welcome' those in London gave to the Glaswegian suffragette Mary Phillips as she left prison in September 1908 and pointedly asked: 'Are you going to send us any active demonstrators from Aberdeen?' noting 'We think that other Scotswomen ought to follow her example'. ${ }^{48}$

Phillips was not the only Scot to feel uncomfortable about the drift towards further militancy, such as stone-throwing and window-smashing. The Glaswegian Helen Fraser made her criticisms of such actions plain. Fraser had developed a high profile in the Scottish press and was a frequent correspondent to the newspapers as the organiser of the Scottish Federation of the WSPU branches. She was often referred to in Scottish newspapers as the leader of the suffragettes. An article in the Dundee Courier in July 1908 explained that Fraser had run the WSPU campaigns in recent elections and had worked independently of the London leadership. 'This called forth complaints from London, and, wishing to have a freer hand, she resigned. Her sympathies, moreover, are not with such tactics as breaking windows in the Premier's house. ${ }^{49}$

It is clear that Helen Fraser and Caroline Phillips were close friends. The correspondence from Fraser in the Watt Collection is written in very affectionate tones, in contrast to the more formal correspondence with London headquarters. Fraser often sent her love and addressed Phillips as 'My dear'. The archive contains a particularly emotional letter from Fraser to Caroline Phillips dated 20th August 1908 after her expulsion from the WSPU. In it, Fraser describes how she "had a very worrying time before I resigned and felt very tired and ill when I did.... It doesn't seem true, even yet, that I am no longer connected with you all' ${ }^{50}$

However, she continued with the news that the NUWSS had asked her to join them and to coordinate their efforts in Scotland, to which she had agreed, and that she had been away 'caravanning for the Cause' around the south of Scotland. Finally, she explained that she had been asked to come up to Aberdeen in September to work with Una Dugdale (a WSPU member) for a meeting and noted that 'Annie' had mentioned Caroline Phillips' kindness to her when she was in Aberdeen.

This letter demonstrates that Helen Fraser was still in contact with members of the WSPU despite her expulsion. Una Dugdale was a young member of an upper-class family from 
Aboyne, Aberdeenshire. She had attended her first WSPU meeting when in London for 'the season' and had been a loyal supporter ever since, accompanying Mrs Pankhurst on several tours of Scotland. In 1912 she married Victor Duval, the founder of the Men's Political Union for Women's Enfranchisement, making headlines when they insisted on the removal of the word 'obey' from the marriage service. ${ }^{51}$ 'Annie' is presumably Annie Kenney, who had visited Aberdeen several times, another loyal supporter of the Pankhursts. The suffrage movement in Scotland, and particularly Aberdeenshire, could ill afford to lose such a valuable organiser and speaker as Helen Fraser. The invitation for her to now use her skills in the organisation of the Scottish constitutional suffragists meant that she continued to work for the cause of women's suffrage, and that, in Scotland, suffragists and suffragettes continued to share platforms and run joint meetings. Helen Fraser's use of a caravan to travel round summer holiday spots on the Scottish and north English coast (donated by the educationist and suffragist Louisa Innes Lumsden of Aberdeen) also demonstrates that the Scottish suffragists were following the suffragettes in engaging more widely with the public and employing such stunts as caravanning. It should, however, also be noted that Helen Fraser's leadership was imposed on the Scottish NUWSS branches by the head office in London. The minute books of the Glasgow and West of Scotland Women's Suffrage Society record their objections to Fraser's appointment, particularly since - as WSPU leader in the city - she had stolen many of their members. The secretary of the Glasgow Society was directed to write to the National Union expressing the Committee's opinion that such an appointment should not have been made without consultation with the Scottish societies and that Helen Fraser would be better employed in England. ${ }^{52}$ Whether they were suffragists or suffragettes, suffrage campaigners in Scotland were learning that London leaderships were not willing to allow independence of thought or action.

After the expulsion of Helen Fraser from the WSPU, Caroline Phillips must have been aware that her own days were numbered. However, she was perhaps not prepared for the way in which it was done. In January 1909 she received a telegram from Christabel Pankhurst starkly stating 'Sylvia Pankhurst arrives Thursday morning to take charge local work. Thursday's meeting had better be abandoned. ${ }^{53}$

The Watt Collection holds a cyclostyled letter that was sent to all members of the Aberdeen branch of the WSPU by Sylvia Pankhurst after she arrived in Aberdeen. ${ }^{54}$ Her arrival was couched in positive language, suggesting that the Aberdeen branch had been so active it had 
been awarded its own permanent representative from headquarters. However, the letter also made it clear that the local branch, with its claims to independence, was to be closed and all members would now be directly enrolled in the national organisation. A new organiser was to be appointed and a new office set up in Union Street. Caroline Phillips was not mentioned by name.

The new organiser sent up by headquarters was the Englishwoman, Ada Flatman. She had been imprisoned for participation in a raid on the House of Commons in October 1908 and had only just been released when she was sent up to Aberdeen. A draft letter in the archive is evidently in response to a meeting between Flatman and Caroline Phillips. ${ }^{55}$ The draft is crossed and re-crossed, making it difficult to read, but there is no doubt of the emotions behind Caroline's words.

It is clear from the letter that other members of the branch had complained about Phillips, possibly because of her attempts at conciliation with the Liberal women or perhaps because of her reticence as far as militant action was concerned. However, her draft reply implies that the complaints had been more personal - suggesting that she had overlooked formalities and had refused to meet to discuss decisions with particular committee members. (It is somewhat ironic that Caroline Phillips lost her role in the WSPU for a leadership style that sounds similar to some of the criticisms of Emmeline and Christabel Pankhurst.) Looking back through the archives, there are several mentions of issues with branch members, particularly Isabella Fyvie Mayo, but the response from London headquarters had always been to take Phillips' side. By 1909, however, there was no support from London and instead Phillips was replaced.

It is interesting, in light of future events, to note that Phillips' critics were also apparently critical of Sylvia Pankhurst's short period of command of the Aberdeen branch. On 22 July 1909 Caroline Phillips received a letter from her friend, Annie McRobie, describing the events at a recent WSPU meeting in Aberdeen. McRobie makes it clear that both Caroline Phillips and Sylvia Pankhurst were heavily criticised at this meeting, and also that Lady Ramsay appeared to have joined the critics. Also attacked were Helen and Constance Ogston, daughters of Professor Francis Ogston of Aberdeen University:

An atmosphere of virtuous indignation pervaded the front benches, and there was something irresistibly funny in the solemnity with which the enormities of our secretary were reeled off from bulky M.S.S. After mauling you beyond all 
recognition, they lashed out against Helen Ogston, gave Constance Ogston a kick in passing, and as a grand finale wiped up the floor with Sylvia Pankhurst.

Helen Ogston was a university graduate in science and a qualified sanitary inspector. The two sisters had joined the WSPU in 1908 and Helen was a frequent speaker on WSPU platforms in London. She was notorious as the suffragette who had wielded a dog whip at an Albert Hall meeting at which Lloyd George was the principal speaker. ${ }^{56}$ Criticism of Caroline Phillips, the Ogston sisters and Sylvia Pankhurst demonstrates that the Aberdeen members of the WSPU by this time were happy to criticise suffragettes from both the militant and more conciliatory sections of the organisation.

A late addition to the archive is a draft letter to Sylvia from Caroline Phillips, reporting on events at the new headquarters of the Aberdeen WSPU in Union Street:

You will be interested to hear that the jackals are re-instated in full favour with Miss Strachan and Miss Flatman. They have had a rendez-vous \& grievances real and imaginary have been fully gone into \& a unanimous verdict given that the National have treated the local Union abominably. The same old lies about your coming and your sayings and doings when you did come have been repeated ad nauseum. ${ }^{57}$

Phillips finished her letter by assuring Sylvia of her support, should any 'vindication of yourself be required' and declaring 'They are welcome to my scalp - so long as the ... movement does not suffer.'

From then on the Aberdeen branch was organised by a succession of activists sent by headquarters and no home-grown leader was allowed the same independence again. It is clear that the London leadership was determined to impose strict controls on the organisation, and would brook no local irregularities or attempts to negotiate WSPU policies to suit local conditions.

Caroline Phillips played no further part in the suffrage campaign. Unlike Helen Fraser she did not join the NUWSS. In December 1913 an article in the Aberdeen Daily Journal noted that a presentation had been made to Miss Phillips on the occasion of her leaving the employment of the newspaper. Her aunt had recently died and bequeathed her the Station Hotel in nearby Banchory and Phillips was to run the hotel for some years. At a ceremony attended by a large 
number of staff, the newspaper presented her with a pair of silver plate entrée dishes while the editor, William Maxwell, made a speech. In a somewhat back-handed compliment, he acknowledged Phillips' suffrage campaigning by 'remarking that if she had decided to devote her whole time to newspaper work she would have proved one of the foremost of lady journalists'. 58

Caroline Phillips died at the age of 85 in 1956 and is buried in the churchyard of Kintore parish church in Aberdeenshire. Her gravestone describes her as 'journalist' ${ }^{59}$ Her obituary in the Aberdeen Evening Express was entitled 'She marched with the Suffragettes' and noted that Phillips had claimed to be Aberdeen's first woman journalist, although it suggested she worked for the Aberdeen Free Press rather than the Journal. ${ }^{60}$ (It also noted that Station Hotel had been a temperance hotel until Miss Phillips had taken it over, when she procured a licence for the premises!) In November 2018, as part of the Rise Up Quines! Festival celebrating the centenary of partial achievement of the vote for women, a plaque was unveiled to the memory of Caroline Phillips on Union Street in Aberdeen. In addition, a mural depicting inspirational women in the history of Aberdeen was created by the ceramicist-activist Carrie Reichardt in St Nicolas Lane as part of Aberdeen's 2018 NuArt Festival. At the centre of the mural is a portrait of Caroline Phillips.

The Watt Collection held at Aberdeen Art Gallery is an important part of the history of the Scottish suffrage movement. It offers a fascinating insight into the conduct and organisation of a WSPU branch in the early years of the WSPU campaign in Scotland and the pressures that might be brought to bear on officers of such a branch, from local politicians, employers and the London leadership of the WSPU. Through her correspondence, Phillips wrestled with the demands of London headquarters for more militant action, was tempted to join the breakaway Women's Freedom League, and finally saw herself and her friend Helen Fraser replaced by the Pankhursts because of a reluctance to become more militant. Because of her involvement in the suffrage movement Phillips found it difficult to gain entrance to political events in the city, making it difficult to complete her work as a reporter, and was threatened with dismissal by her employer. She was also torn between the demands for increasing militancy from the WSPU leadership and her own instinct for a more conciliatory approach, in particular in relation to the dominant Liberal Women's Association in Aberdeen. Her correspondence reveals the emotional and personal costs of working for the cause in a city far 
away from the heart of the suffrage movement, but also the fulfilling friendships with women such as Helen Fraser, Annie McRobie and Sylvia Pankhurst that sustained and supported her.

\footnotetext{
${ }^{1}$ Sarah Pedersen, Caroline Phillips: Aberdeen Suffragette and Journalist (Aberdeen: RGU, 2018)

${ }^{2}$ Alison Taylor McCall, Kintore Historical Notes, http://www.kintore.org.uk/history/phillips/\#.XD8DoqrA X4 accessed 14 January 2019

3 'Women's Emigration to South Africa', Aberdeen Daily Journal 18 September 1901

${ }^{4}$ Sarah Pedersen, The Scottish Suffragettes and the Press (London: Palgrave Macmillan, 2017)

5 'How the World Wags', Motherwell Times, 29 May 1914

${ }^{6}$ Helen Tollie, letter to the editor, Aberdeen Daily Journal, 30 July 1912

${ }^{7}$ James Curran, 'Media and the making of British Society, c. 1700-2000', Media History, 8, no. 2 (2002): 135 54

${ }^{8}$ Rosemary Goring, The Herald's Coverage of Women's Issues. The Herald 225 Years: 1783-2008 (Glasgow: Glasgow Herald, 2008)

${ }^{9}$ Krista Cowman, Women of the Right Spirit: Paid Organisers of the Women's Social and Political Union (WSPU) 1904-18 (Manchester: Manchester University Press, 2007), 45

${ }^{10}$ Aberdeen Art Gallery, The Watt Collection no. 2, 17 April 1907

${ }^{11}$ Aberdeen Art Gallery, The Watt Collection no. 6, 16 September 1907

${ }^{12}$ Aberdeen Art Gallery, The Watt Collection no. 1, 13 April 1907

13 'Late Rev. Alexander Webster', Aberdeen Daily Journal, 15 October 1918

${ }^{14}$ Elspeth King, The Hidden History of Glasgow's Women. (Edinburgh: Mainstream Publishing, 1993)

${ }^{15}$ June Purvis, Emmeline Pankhurst: A Biography (London: Routledge), 92

${ }^{16}$ Aberdeen Art Gallery, The Watt Collection no. 43, 14 May 1908

${ }^{17}$ Aberdeen Art Gallery, The Watt Collection no. 65, undated

18 Aberdeen Art Gallery, The Watt Collection no. 11, 26 September 1907

19 'Scottish Women Suffragists: Demonstrations in Edinburgh', The Scotsman, 7 October 1907

${ }^{20}$ Aberdeen Art Gallery, The Watt Collection, no. 14. Printed invitation to be on the platform at the meeting at Synod Hall on 5 October 1907

${ }^{21}$ Aberdeen Art Gallery, The Watt Collection no. 9. Printed invitation for an event on 21 September 1907

22 Aberdeen Art Gallery, The Watt Collection no. 8, 20 September 1907

${ }^{23}$ Aberdeen Art Gallery, The Watt Collection no. 10, 24 September 1907

${ }^{24}$ Cowman (2007), 151

${ }^{25}$ Aberdeen Art Gallery, The Watt Collection no. 16. Constitution of the Women's Freedom League (printed)

${ }^{26}$ Aberdeen Art Gallery, The Watt Collection, no. 17. Winter Syllabus 1907-08 for the Women's Freedom League (printed)

${ }^{27}$ Aberdeen Art Gallery, The Watt Collection no. 63, no date

${ }^{28}$ Elspeth King, The Hidden History of Glasgow's Women. (Edinburgh: Mainstream Publishing, 1993), 109

${ }^{29}$ Aberdeen Art Gallery, The Watt Collection no. 18, 18 November 1907

30 'Liberals and votes for women: Address by Miss Helen Fraser', Aberdeen Daily Journal, 1 February 1907

${ }^{31}$ Isabella Fyvie Mayo, letter to the editor, Aberdeen Daily Journal, 11 February 1907

${ }^{32}$ Mrs Black and Mrs Allan, letter to the editor, Aberdeen Daily Journal, 19 January 1907

${ }^{33}$ Helen Fraser, letter to the editor, Aberdeen Free Press, 12 February 1907

${ }^{34}$ Caroline Phillips, letter to the editor, Aberdeen Daily Journal, 22 November 1907

${ }^{35}$ Aberdeen Art Gallery, The Watt Collection no. 20, 22 November 1907

${ }^{36}$ Aberdeen Art Gallery, The Watt Collection no. 21, 28 November 1907

${ }^{37}$ Aberdeen Art Gallery, The Watt Collection no. 22, 6 December 1907

${ }^{38}$ Cowman (2007), 49

${ }^{39}$ Aberdeen Art Gallery, The Watt Collection no. 23, 10 December 1907

${ }^{40}$ Aberdeen Art Gallery, The Watt Collection no. 24

${ }^{41}$ Caroline Phillips, letter to the editor, Aberdeen Daily Journal, 24 December 1907
} 


\footnotetext{
42 Aberdeen Art Gallery, The Watt Collection no. 27, 28 December 1907

${ }^{43}$ Aberdeen Art Gallery, The Watt Collection no. 26, no date

${ }^{44}$ Aberdeen Art Gallery, The Watt Collection no. 32, 11 January 1908

45 Aberdeen Art Gallery, The Watt Collection no. 36, 5 February 1908

${ }^{46}$ Aberdeen Art Gallery, The Watt Collection no. 37, 6 February 1908

${ }^{47}$ Aberdeen Art Gallery, The Watt Collection no. 34, 18 January 1908

${ }^{48}$ Aberdeen Art Gallery, The Watt Collection no. 46, 18 September 1908

49 'Suffragette Split', Dundee Courier, 8 July 1908

${ }^{50}$ Aberdeen Art Gallery, The Watt Collection no. 44. 20 August 1908

${ }^{51}$ Crawford (1999), 178

${ }^{52}$ Mitchell Library, Glasgow and West of Scotland Association for Women's Suffrage Executive Committee Minute Book 1902-1905 891036/1/1, 4 September 1908

${ }^{53}$ Aberdeen Art Gallery, The Watt Collection no. 48. 5 January 1909

${ }^{54}$ Aberdeen Art Gallery, The Watt Collection no. 49. 7 January 1909

55 Aberdeen Art Gallery, The Watt Collection no. 51. 9 February 1909

${ }^{56}$ Crawford (1999), 472

${ }^{57}$ Aberdeen Art Gallery, The Watt Collection no. 55. No date

58 'Presentation to Miss C. A. I. Phillips', Aberdeen Daily Journal, 24 December 1912

${ }^{59}$ Alison Taylor McCall, Kintore Historical Notes

60 'She marched with the Suffragettes', Aberdeen Evening Express, 14 January 1956
} 